\title{
Once more on the language of the documents from Niya (East Turkestan) and its genetic position
}

\begin{abstract}
The language of the documents found in the Southeast of present day Xinjiang, mainly in the Niya oasis, is usually reckoned among the Middle Indo-Aryan languages. Some scholars, however, believe it to be a possible ancestor of certain Dardic dialects. In the present article an attempt is made to resolve this controversy, and to establish the exact position of the Niya Prakrit in the Indo-Iranian group. The author concludes that the language in question can by no means be classified as Dardic, though in the past its speakers may have been neighbors of the Dards.

Keywords: Indo-Aryan languages, Dardic languages, language classification, historical phonology, Northwestern Prakrit, Niya Prakrit, East Turkestan, Kroraina kingdom
\end{abstract}

The language of the administrative documents discovered in East Turkestan, on the territory of the erstwhile kingdom of Kroraina, chiefly in the Niya oasis ${ }^{1}$, is usually considered a Middle Indo-Aryan language ${ }^{2}$. At the same time, some scholars hypothesize that it may be ancestral to certain Dardic dialects. In the past, when the Dardic group was mostly regarded as a subbranch (or several subbranches) of Indo-Aryan, these two viewpoints did not seem to be in conflict. Recent research has, however, shown that the Dardic languages cannot be classified as Indo-Aryan but should rather be regarded as a separate branch of the Indo-Iranian group (Kogan 2005). In the light of this fact, it must be recognized that the two above-cited hypotheses concerning the genetic affiliation of the Niya Prakrit are mutually exclusive, and the issue still remains unsolved. In the present article I shall make an attempt to establish, at least in a first approximation, the position of the Niya Prakrit in the genealogical classification of the Indo-Iranian languages. This task can hardly be carried out without a thorough analysis of arguments adduced in favor of each of the two competing theories.

Soon after the discovery of the Niya documents their language was recognized by Stein as Middle Indo-Aryan ("Prakrit") 3 . Detailed research on the subject was initiated later by the British Indologist and Dravidologist Thomas Burrow. In a special paper dedicated to this problem (Burrow 1936), he managed to show that the Niya Prakrit shares a number of common phonological and morphological isoglosses with three Indo-Aryan forms of speech, namely, the language of the Kharoșthi manuscript of the Buddhist poetic text Dhammapada ${ }^{4}$,

\footnotetext{
${ }^{1}$ The kingdom of Kroraina was known as Shanshan to the Chinese. Its territory covered the chain of oases located on the southeastern rim of the Taklamakan Desert (now in the Xinjiang Uyghur Autonomous Region of China). Niya was the westernmost oasis, bordering upon Khotan, another powerful kingdom of the area. Documents representing the official language of Kroraina were discovered in the early $20^{\text {th }}$ century by the renowned British archaeologist, historian and traveler Sir Aurel Stein. All of them were written in the Kharoșți script and date back to the $3^{\text {rd }}$ century AD.

${ }^{2}$ For this reason, it is often called the Niya Prakrit.

${ }^{3}$ See, e.g. Stein 1904.

${ }^{4}$ This language is usually called the Gandhari Prakrit. The manuscript of Dhammapada was discovered near Khotan at the close of the $19^{\text {th }}$ century by an expedition led by the French geographer Dutreuil de Rhins. Until recently this text had been the only available specimen of Gandhari, but since the 1990s multiple new manuscripts were found in Pakistan and Afghanistan. For their overview, see Salomon 2006.
}

Journal of Language Relationship • Вопросы языкового родства • 15/4 (2017) • Pp. 228-237 • ( The authors, 2017 
the language of king Aśoka's edicts found at Mansehra and Shahbazgarhi (now in northwestern Pakistan), and the language of later Kharoșthi inscriptions discovered in the northern part of the Indus valley as well as in the areas west of the Indus, including the present-day Afghanistan. The last of these languages shows the greatest resemblance to the Niya Prakrit, and is, possibly, most closely related to it. The reason for such a conclusion is the presence of a significant number of shared innovations, both in phonology (the development of certain old

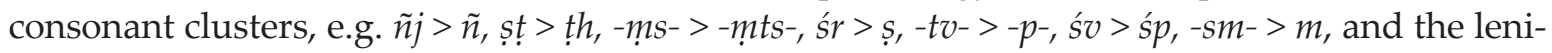
tion of intervocalic single consonants ${ }^{5}$ ) and morphology (the nominative singular in $-e^{6}$ ).

The language of Aśoka's inscriptions, too, possesses certain features, common with the Niya Prakrit7, but some of them are shared retentions, and thus cannot be relevant for genealogical classification. Common phonological and morphological innovations also exist (e.g. $r>$ $r i, r u$; șy > ś; infinitive in -anaye; indeclinable participle in -ti) but are relatively few in number. Moreover, the Niya documents, being 600 years younger than Aśoka's edicts, reflect in some cases a more archaic linguistic state in comparison with the latter ${ }^{8}$. It means that the language of these documents can in no way be the descendant of the northwestern inscriptional Aśokan Prakrit.

As for the Gandhari Prakrit, the situation there seems to be far from clear. In this language, there are many instances of irregularity in phonological development, the same Old Indian phoneme or phonemic sequence often displaying different reflexes in the same position ${ }^{9}$. Burrow (1936) attributed this fact to the influence of the Indo-Aryan dialect in which Dhammapada was originally composed. Since this dialect remains unknown to us, Burrow's conjecture can be neither proved nor disproved. One should also bear in mind that the Gandhari Prakrit, like some other Middle Indo-Aryan literary languages, can to a great extent be an artificial construct, obtained from Sanskrit by applying certain historical phonological rules, which, in practice, were not always strictly observed ${ }^{10}$.

On the basis of the above-mentioned phonological and morphological isoglosses, Burrow concluded that the area where the language of the Niya documents had originally been spoken was situated west of the Indus, presumably in the area of Peshawar. The spread of this language as official in East Turkestan must, in his opinion, have taken place in the $1^{\text {st }} 3^{\text {rd }}$ centuries AD under the Kushan Empire, of which the Kroraina kingdom was a remnant ${ }^{11}$. This conclusion seems to be the most plausible one at the current state of our knowledge.

However, it was Burrow who had created some confusion in the historical study of the Niya Prakrit. In the above-cited article he argued that "most of the phonetic peculiarities of this dialect reappear in the modern Dardic languages", and "a few of the phonetic developments are particular to Torwali” (Burrow 1936: 434). The first of these two statements is simply wrong and misleading. Modern Dardic languages differ considerably from each other as re-

\footnotetext{
${ }^{5}$ For further details and examples, see Burrow 1936.

${ }^{6}$ In the Niya Prakrit there are clear historical traces of this nominative ending, though in most cases it was replaced by the accusative marker - $a$ (Burrow 1936).

${ }^{7}$ For a complete list and analysis, see Burrow 1936.

${ }^{8} \mathrm{Cf}$. the preservation of the clusters $-r t-,-r t h-,-r d h-,-r s ̦-,-l p-,-l y-,-t s-$ in Niya vs. their simplification in Aśokan.

${ }^{9}$ For examples, see Burrow 1936.

${ }^{10}$ It should be noted that in modern literature Gandhari and Niya are often considered as two varieties of the same Prakrit (see e.g. Hock, Bashir 2016). Historical phonological facts, however, clearly show that this view is wrong, and the frequent use of the umbrella term "Northwestern Prakrit" for both languages is hardly warranted.

${ }^{11}$ On Kushan influence in East Turkestan see e.g. Millward 2013. It is believed by some scholars that the Ku-

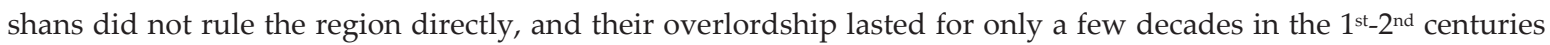
A.D. (Hitch 1988). Their impact on the local culture was, however, very great.
} 
gards historical phonology, and the whole set of sound changes, listed by Burrow, is by no means peculiar to all of them. As for the "phonetic developments", common for Niya and Torwali ${ }^{12}$, the scholar specifies only three of them, namely:

1) $s v>s ́ v$ (cf. Niya śvasu, Torwali šu 'sister', OIA svasr-id.);

2) śv > śp (cf. Niya aśpa, OIA aśva- 'horse'; Niya śpeta, OIA śveta- 'white'; Torwali paiṣ (< *śpașū), OIA śvaśrū- 'mother-in-law');

3) $s m>m$ (cf. Niya amahu 'our', Torwali mō 'we', OIA asmabhyam pers. pron. 1 Pl Dat).

It is worth noting that changes 2 and 3 on this list show exact or approximate parallels in many languages of the area. The development of OIA śv to śp (<PII * śu) is typologically similar to the process that affected the same Proto-Indo-Iranian consonant cluster in Iranian, where it has changed to $s p$ in most languages, including Avestan ${ }^{13}$. The reflex of OIA intervocalic -sm-, identical to that in Niya, is not infrequently found in New Indo-Aryan (cf. Hindi ham, Gujarati, Romany ame, Bengali amra, Assamese ami, Oriya āme, Nepali hāañ 'we', Hindi hamārā, Gujarati amārũ, Romany amaro, Nepali hāmro 'our'). Both these historical phonological phenomena, being geographically widespread, can hardly be diagnostic for genealogical classification.

There is, however, a more important reason to consider the close affinity of Torwali to Niya improbable. The Torwali language belongs to the Kohistani subbranch of the East Dardic branch of the Dardic group. Glottochronological calculations, recently performed for this group ${ }^{14}$, indicate that the split of Proto-Kohistani dates back to the $3^{\text {rd }}$ century A.D., i.e. to the very period of time in which the extant texts from Kroraina were written. It means that the Niya Prakrit may theoretically belong to the Kohistani subbranch, if at all, only as its protolanguage. But there is strong evidence against such an assumption. None of the three abovementioned phonological changes can be postulated for the Proto-Kohistani state, since certain Kohistani languages show a totally different development for all the three old clusters just discussed. Cf., e.g., their reflexes in Indus Kohistani: *sv>s (sazū 'nephew, sister's sun' < *svāsrka-); *śv > š ( ̌̌ūr 'father-in-law' < *śvaśura-), *-sm- > *-s- > z (zã pers. pron. $1 \mathrm{Pl} \mathrm{Obl} \mathrm{<} \mathrm{*asmad-).}$

It should thus be recognized that no true historical phonological isogloss, which could give us a reason to classify the language of the Niya documents as Dardic, has been found so far. Nevertheless, the problem of genetic relations between the Niya Prakrit and the Dardic group is far from being solved. The most proper way to clarify this issue is, no doubt, to analyze the behavior of the language under study in those cases where Indo-Aryan and Dardic show divergent development. The extant material allows us to detect three such cases, i.e. the reflexes of the Proto-Indo-Iranian syllabic ${ }^{*} r$, voiced aspirates, and certain Proto-IndoEuropean consonant clusters with initial velars. Each of these phonological processes will be discussed at some length below.

The usual Niya reflex of the Proto-Indo-Iranian syllabic ${ }^{*} r$, and the usual correspondence to the same phoneme in Old Indo-Aryan, is ri: grihasta 'householder' (cf. OIA grhastha-), ghrida 'clarified butter, ghee' (cf. OIA ghrta-), drițha 'seen' (cf. OIA drșța-), prithivi 'earth' (cf. OIA prth(i)vi-), prichati 'asks' (cf. OIA prcchati), krita 'done' (cf. OIA $k r t a-$ ). Isolated cases of the change ${ }^{*} r>r u$ have also been noted (cf. pruch- 'to ask'). Not infrequently the old syllabic ${ }^{*} r$ is

\footnotetext{
${ }^{12}$ Torwali is a Dardic language spoken in the upper reaches of the Swat valley in Northwestern Pakistan.

${ }^{13} \mathrm{Cf}$. also the change śs $>s$ in most Iranian languages.

${ }^{14}$ See Kogan, Vasilyev 2013; Kogan 2016.
} 
written unchanged: rna 'debt' (cf. OIA ṛna-), krta 'done' (cf. OIA krta-), grhha 'house' (cf. OIA grha-), mrda 'dead' (cf. OIA mrta-), prchati 'asks' (cf. OIA prcchati) ${ }^{15}$. Burrow (1937: 2) has reasonably assumed that the preservation of ${ }^{*} r$ in the latter series of examples is a purely orthographical phenomenon, and that the respective Kharoșthi character, in reality, conveys the sequence $r i$ or $r u$. This hypothesis is strongly supported by the fact that the same words may have two different spellings (cf. krita and $k r t a ;$ prichati and prchati).

In a number of cases the syllabic $r$ is vocalized: kișaṃnae 'to plough' (cf. OIA krșati 'ploughs'), kiḍa 'done' (cf. OIA krta-), prahuḍa 'gift' (cf. OIA präbhrta-). The retroflexization of dentals after the resonant seems to be a regular process in such examples, which is most likely connected with another one, namely the change of an intervocalic dental into retroflex accompanying the loss of $r$ in the initial consonant cluster (cf. Niya padi = OIA prati 'towards, against'). It means that the vocalic reflex of the syllabic $r$ can in certain instances be the result of some specific development of an earlier ri- or ru-like reflex ${ }^{16}$. E.g. prahuda 'gift' could have evolved from prābhrta- through the intermediate stages *prābhruda and *prābhuda, the cluster $b h r$ being simplified to $b h$ due to dissimilation.

No unquestionable instances of syllabic $r$ vocalized in word-initial position have been found in the Niya documents thus far. The only form where this sound change can be supposed to have taken place is anahetu 'because of the debt', but this example is very doubtful. As Burrow (1937: 74) has pointed out, the initial element ana-should not necessarily reflect the older rna- 'debt', but could be the extended form of the negative prefix $a n^{-17}$. In the latter case the meaning should be 'without cause' (cf. hetu 'cause'). Such an interpretation is by no means excluded by the context ${ }^{18}$ and, at the same time, seems to be preferable from the viewpoint of historical phonology, because, as has already been noted, the continuant of rna-is attested in the Niya Prakrit as rna.

In the light of all these facts, the phonemic sequence " $r+$ vowel" should be considered as the most probable reflex of Proto-Indo-Iranian syllabic ${ }^{*} r$ in the language of the Niya documents. Such a development is very frequent in Indo-Aryan and, as stated above, characteristic of Northwestern inscriptional Aśokan Prakrit. In Old Indian the syllabic ${ }^{*} r$ had, in all probability, already been pronounced with postvocalization. This fact follows not only from the traditional pronunciation of the corresponding written character as ri or $r u$ in the modern declamation of Sanskrit texts but also from interchangeability of $r$ and $r i$ in certain lexemes (cf., e.g. krmi- and krimi- 'worm'). In New Indo-Aryan languages $r \check{\bar{l}}$ is the usual reflex of OIA $r$ in the initial position: Sindhi richu, Punjabi ricch, Hindi rīch, Gujarati rīch, Marathi rīs, Garhwali, Kumauni rīkh, Romany rĩ̌ 'bear' < OIA r rkșa-; Lahnda rịnn, Punjabi, Hindi, Nepali rin, Oriya riṇa, Marathi, Garhwali rīn, Konkani rinna 'debt' < OIA rna-; Lahnda rijh- 'to be allured, to be amused', Nepali, Oriya rijh- 'to rejoice', Hindi rījh- 'to be enchanted', Gujarati, Marathi rijh- 'to be pleased' < OIA rdhyati 'prospers' ${ }^{19}$ ).

In Dardic the development of Proto-Indo-Iranian ${ }^{*} r$ is different. Although there are several examples of ri- and ru-type reflexes (cf. Kalasha krizna, Kashmiri kruhun 'black', OIA krș̣na- id.; Kashmiri prich-, prìch- 'to ask', OIA prcchati 'asks'; Phalura drhiștu (<* drișțu) 'seen',

\footnotetext{
${ }^{15}$ For more examples see Burrow 1937.

${ }^{16}$ Naturally, it cannot be ruled out that a number of Niya words with vocalization are borrowed from some other Indo-Aryan dialect, as per Burrow 1937: 2.

${ }^{17}$ This secondary ("extended") negative prefix ana- is attested in Prakrit.

${ }^{18}$ The respective document reports that a woman, perhaps a female slave, was carried off anahetu, which can be understood both as 'because of the debt (of the woman's owner)' and as 'without (apparent) cause'. It is remarkable that Burrow himself ultimately preferred the translation “without just cause” (Burrow 1940: 143-144).

${ }^{19}$ Cf. rdhati 'increases, prospers, succeeds'. The form r rdhyati is attested in Panini's Dhātupātha (Turner 1966: 117).
} 
OIA drșta-id.), they may well reflect a relatively recent phonological process, known as "Dardic metathesis". This process consists of the transposition of $r$ from non-initial consonant clusters to the position after the initial consonant, leading to the formation of a new cluster ${ }^{20}$ : Kalasha krum, Tirahi, Phalura kram, Shina krom, Bashkarik $\lambda \bar{a} m\left(\lambda<{ }^{*} k r\right)$ 'work', OIA karman- id.; Pashai drāet, Kashmiri drōt 'sickle', OIA dātra- id.; Kashmiri trām 'copper', OIA tāmra- id. As for those lexemes where the "Dardic metathesis" has not taken place ${ }^{21}$ and those positions where it was impossible (particularly, word-initially), we find clear traces of the change ${ }^{*} r>$

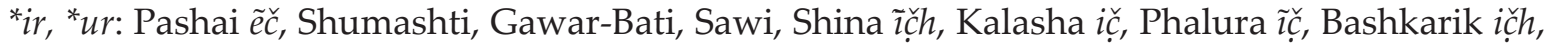

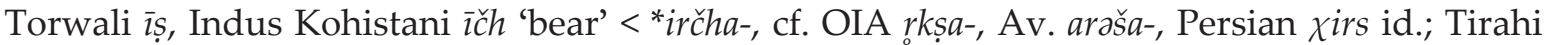
wuṛ, Kalasha hĩra, Gawar-Bati hira, Phalura, Sawi hiṛo, Shina hiru 'heart'22, cf. OIA hrdaya-, Av. zarəSaya- id.; Bashkarik mur, Katarqalai mur, Phalura muro 'died' < *mrta-23. It is quite reasonable to consider this development as an original Proto-Dardic phenomenon. It separates the Dardic languages from the Indo-Aryan family and makes them similar to the Iranian, Nuristani, and most non-Aryan Indo-European languages, where old syllabic $r$ also yields phonemic sequences with an initial vowel (Edelman 1986: 33-34; Kogan 2005: 22-25).

$* * *$

Proto-Indo-Iranian and Proto-Indo-European voiced aspirated stops are usually preserved in Indo-Aryan, but they lose aspiration and merge with their voiced unaspirated counterparts in Dardic, Iranian and Nuristani. The situation in the Niya Prakrit is in certain respects unclear, because the original picture was obscured to a great extent by extensive contact effects. The language under study, being official in the kingdom of Kroraina, was most probably not native to the great majority of its people. Their mother tongue, as Burrow has demonstrated, may well have been some local form of Tocharian ${ }^{24}$, which did not distinguish between aspirated and unaspirated, or between voiced and voiceless consonants (Burrow 1935). The influence of this vernacular resulted not only in the adoption of loanwords but also in frequent scribal errors reflecting phonological interference. One of them was the confusion of aspirates and nonaspirates (cf., e.g. śavata and śavatha 'oath', cimnita and chimnida 'cut', gașa and ghasa 'fodder', grida and ghrida 'clarified butter, ghee', divașa and dhivașa 'day', dita and dhida 'given', baǵa and bhaǵa 'share', buma and bhuma 'land', biti and bhiti 'second' ${ }^{25}$ ).

It should be noted, however, that in the intervocalic position reflexes are much more regular than word-initally. In particular, the old voiced aspirates almost always change to $h$ between vowels: lahaṃti '(they) receive' (cf. OIA labhante), parihașa 'claim' (cf. OIA paribhāșa-), prahuda 'gift' (cf. OIA prābhrta-), gohomi 'wheat' (cf. OIA godhūma-), ahuno 'now' (cf. OIA adhunā),

${ }^{20}$ For more details see Morgenstierne 1947. Besides Dardic, this phenomenon is also attested in some IndoAryan languages, e.g. in Northwestern Aśokan and Gandhari Prakrits, and in the dialects of Lahnda and Hindko. Crucially, it is not characteristic of the Niya Prakrit.

${ }^{21}$ One of the reasons why this sound change did not occur in a number of lexemes may be the fact that it could have yielded certain consonantal groups, such as $h r$ or $m r$, which are quite uncommon in a number of Dardic languages.

${ }^{22}$ Tirahi, Gawar-Bati, Phalura, Sawi, Shina $r$, Kalasha $\dot{r}<{ }^{*} r d$.

${ }^{23}$ Bashkarik $r<{ }^{*} r<{ }^{*} r t$, Katarqalai, Phalura $r<{ }^{*} r t$.

${ }^{24}$ Since it is certainly not identical to any of the two known Tocharian languages (Tocharian A and Tocharian B), it is often called Tocharian C.

${ }^{25}$ For more examples, see Burrow 1937: 9-10. The above-cited forms dhivasa (cf. OIA divasa- 'day'), dhida (cf. OIA datta- 'given') and bhiti (cf. OIA dvitiya- 'second') clearly show that the confusion of the two series in the Niya orthography could manifest itself not only in the irregular absence of historical aspiration, but also in graphic aspirates in lieu of etymological non-aspirates. 
lahu 'light (adj.)' (cf. OIA laghu-). On the contrary, the old voiced unaspirated stops never undergo this change. In most cases they are either preserved or develop into fricatives: agachati 'comes' (cf. OIA agacchati), nagara 'town' (cf. OIA nagara-), bhaǵa 26 'share' (cf. OIA bhāga-), pada 'foot' (cf. OIA pāda-), udaǵa 'water' (cf. OIA udaka-), paribujiśatu 'you will understand' (<*paribudhya-, cf. OIA paribodha- 'reason'). Isolated cases of devoicing are also attested: utarā 'belly' (cf. OIA udara-).

The evident distinction between the intervocalic reflexes of aspirates and non-aspirates does not allow us to include the Niya Prakrit into the Dardic branch, where the merger of the two series seems to have taken place already in the protolanguage ${ }^{27}$. Of special interest in this respect is the behavior of the Proto-Indo-Iranian bifocal voiced aspirated affricate ${ }^{*} j h$ (< PIE ${ }^{*} g h,{ }^{*} g^{w} h$ in the palatalizing position). It changes to $h$ in both Old Indic and in the language of the Niya documents, whereas in Dardic it loses aspiration: Niya dahita 'burnt', OIA dahati 'burns', Torwali daž-, Indus Kohistani daz-, Katarqalai dazā- 'to burn (tr.)', Kashmiri daz-, Phalura, Sawi daj-, Shina daž- 'to burn (intr.)' < PII *dajh- < PIE *dhegwh-; Niya nihamnñitavo 'should be killed, should be stricken? ${ }^{28}$ ', OIA hanti, nihanti 'strikes, kills', nihata- 'slain', Prakrit ṇihanaï 'strikes, throws', Hindi nihan- 'to strike, kill', Kashmiri bizan- 'to thrust something down (e.g. a pole into a hole)' ${ }^{29}<$ PII *jhan- 'to strike, kill' < PIE * ${ }^{*}$ when-.

\section{$* * *$}

The Proto-Indo-European consonant clusters ${ }^{*} k s$ and ${ }^{*} k$ 's behave differently in different branches of Indo-Iranian. In Old Indian they have merged into $k s ̦$, whereas in Iranian the distinction between them is preserved, and their reflexes are ${ }^{*} \chi \check{s}$ and ${ }^{*} \check{s}$ respectively. In ProtoDardic the situation is somewhat similar to the Iranian one: no merger of the two consonantal groups has taken place, the development being ${ }^{*} k s>{ }^{*}{ }^{3} h^{30},{ }^{*} k^{\prime} s>{ }^{*} c h$ (Kogan 2005). The same historical phonological processes affected the PIE clusters *tk and * $t k^{\prime}$, in which the voiceless Brugmann spirant ${ }^{*} p$ was reconstructed in the past ${ }^{31}$. The former cluster reflects in Iranian and Dardic exactly like ${ }^{*} k s$ and the latter exactly like ${ }^{*} k$ 's. In the Niya Prakrit, on the other hand, there seems to be only one correspondence to OIA $k s ̦$ irrespective of its origin: čhetra 'field' (cf. OIA kșetra- 'field, land, region', kșayati 'lives, resides', Av. šōi Ora- 'region, district', šaèitī 're-

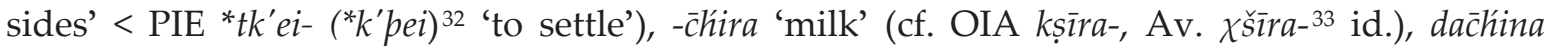
'right' (cf. OIA dakșina-, Av. dašina- id. < PIE *dek's-34), račhișyati '(he) will guard' (cf. OIA

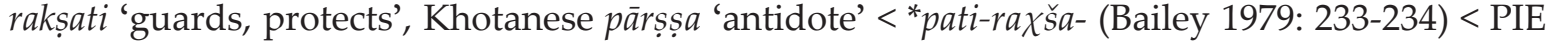
*alek-s-), śičíatu 'learn! (Imp)' (cf. OIA śikșate, śikșati 'learns, studies', Av. a-sixšaṇt 'not learning'), vrc̄ha 'tree' (cf. OIA vrkșa-, Av. varaša-< PIE *ul $\left.k_{0} k^{\prime} s-0-{ }^{35}\right)$.

${ }^{26}$ Following Burrow, I employ the letter $g$ to transcribe the voiced velar fricative.

${ }^{27}$ In several Dardic languages, e.g. in Torwali and Indus Kohistani, there are voiced aspirates of secondary origin. Their appearance is most probably a result of Indo-Aryan influence (Kogan 2008).

${ }^{28}$ If $<{ }^{*}$ ni-han-, and not < ${ }^{*}$ ni-khan- (Burrow 1935: 671).

${ }^{29}$ Kashmiri bizan- < PII *abhi-jhan- (Kogan 2005: 35).

${ }^{30}$ Possibly at the earliest stage of Proto-Dardic the reflex was ${ }^{*} k s$ or ${ }^{*} k s ̦$, but later this cluster changed to the voiceless retroflex aspirated affricate çh, regular continuants of which are found in all the Dardic languages.

${ }^{31}$ In Pokorny's dictionary (Pokorny 1959) they appear as ${ }^{*} k p$ and ${ }^{*} k$ respectively.

${ }^{32}$ Pokorny 1959: 626.

${ }^{33}$ Although the PIE prototype of this word is still unclear, the cluster $\chi \check{s}$ in Iranian points to a plain velar ${ }^{*} k$ in the proto-form.

${ }^{34}$ Pokorny 1959: 191.

${ }^{35}$ Mayrhofer 1996: 572. 
The actual pronunciation of the Kharoșthi letter that is traditionally transliterated as $\bar{c} h^{36}$ remains a controversial issue. Sten Konow (1936: 610) was of the opinion that it conveyed the retroflex affricate ç̣h. If this hypothesis is true, it will mean that in many cases the Niya Prakrit is remarkably alike to Dardic as regards the behavior of the above-mentioned Proto-IndoEuropean clusters. The greatest similarity is to the languages of the East Dardic subbranch, where Proto-Dardic *ch (< PIE * $\left.k^{\prime} s,{ }^{*} t k^{\prime}\right)$ acquires postalveolar articulation in most positions. Being similar, these two phonological changes are, nevertheless, not identical. As I have demonstrated in my recent book (Kogan 2016), retroflexization of the original palatal *ch in East Dardic has failed to take place before the historical short vowel of the final syllable. The language of the Niya documents, however, does not show any deviation from the general pattern in this position (cf. vrçcha 'tree' < PIE * $u_{-0} k^{\prime} s-0-{ }^{37}$ ).

Another hypothesis concerning the phonological nature of the Kharoșthi čch affirms that this character might have represented the unchanged cluster $k s$ (Burrow 1937: 18). If Burrow's interpretation holds water, then the Niya development of PIE ${ }^{*} k s,{ }^{*} k$ 's, ${ }^{*} t k$, ${ }^{*} t k^{\prime}$ should be considered as identical to the Old Indian one.

The facts analyzed above suggest the conclusion that no historical phonological features that are peculiar to Dardic as opposed to Indic can be found in attested Niya material. In those cases when the development in the two branches differs, the Niya Prakrit always follows Indo-Aryan, which means that there is no reason to classify this language as belonging to the Dardic group. Nevertheless, it shares a few apparent lexical isoglosses with Dardic, which deserve a special discussion. These are Niya patama 'back' (cf. Kashmiri pot 'hinder, subsequent', patï 'after', Shina phatu, Indus Kohistani patō, Torwali pat 'behind', Bashkarik, Pashai pat 'after', Gawar-Bati pata 'behind') and Niya jaṃdu- 'snake' 38 (cf. Shina jon, Phalura jhandura, Indus Kohistani zan, Torwali jān, Gawar-Bati ziant, Shumashti zãt 'snake', OIA jantu- 'offspring, creature; insect, worm').

The first of these two etyma is also present in Nuristani (cf. Ashkun pat $\widetilde{e}$, Waigali patai 'after') and probably in Iranian ${ }^{39}$. As for the New Indo-Aryan languages, it is found only in a few of them, namely in certain Pahari dialects (cf. Bhalesi patte 'behind', Bhidlai pettio 'hinder') ${ }^{40}$. Both Bhalesi and Bhidlai are in contact with Kashmiri, a language of the Dardic group. This implies a high probability of borrowing from Dardic into Indo-Aryan, and it can be assumed without additional complications that a similar process might have taken place in the Middle Indian period and affected some early form of the Niya Prakrit.

The second of the above-mentioned isoglosses seems to be disputable. The actual meaning of the Niya word jam it as 'snake', pointing out that it corresponds to Khotanese śaysdi with the same meaning in a text dealing with the 12-year animal cycle. On the other hand, Burrow (1937: 92) preferred to

${ }^{36}$ This letter is similar to the letter for ch, differing from it only by the presence of a cross-bar above. This cross-bar usually functions in the Kharoșthi script as the sign of gemination.

${ }^{37}$ Secondary cerebralization in the Niya word is highly improbable because, as has already been shown, this process was always accompanied by vocalization of the syllabic $r$.

${ }^{38}$ The word is attested in the genitive plural form jamdunamca.

39 Turner (1966: 436) compares all the above-cited Dardic and Nuristani words with Av. paiti 'towards; against; back; with' (< Proto-Iranian * pati).

${ }^{40}$ The etymology of Kumauni patìr 'after, beyond' remains unclear, and this word can thus hardly be considered a secure cognate of the Dardic forms listed above. 
translate jamidunamca as 'worms'. If Bailey's interpretation is the correct one, we can postulate a Niya-Dardic semantic parallel. It may, however, represent a result of either language contact or homoplasy, because the semantic change 'worm' > 'snake' ${ }^{41}$ is typologically quite frequent

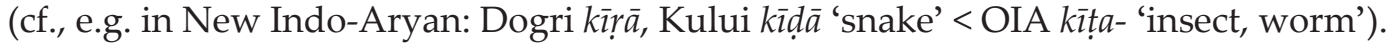

The two isoglosses just analyzed show that although the Niya Prakrit does not belong to the Dardic group, its speakers during a certain period of time may have been neighbors of the Dards. This conjecture agrees well with Burrow's conclusion that the region where the language under study was originally spoken included the Valley of Peshawar, which is located immediately to the south of the Dardic-speaking area.

Another important issue arising in connection with the language of the Niya documents is its relation to the modern languages of South Asia. Given that its phonology and morphology do not display any features that cannot be derived from Old Indian, it can hardly be doubted that the Niya Prakrit should be classified together with the Indo-Aryan branch. Its exact position within this branch is, however, far from being clear. Certain historical phonological isoglosses bring it closer to the languages of the North-West, i.e. to Sindhi, Lahnda, Punjabi and West Pahari dialects. Cf., e.g. the development of old consonant clusters with initial nasals: Niya $\tilde{n} j>$ $m \tilde{n}$ (gaṃñavara 'treasurer' < OIA gañjavara-42), Sindhi $\tilde{n} j>\tilde{n}$ (piñaro 'cage; ribs' < OIA pañjara-, piñjara- 'cage; skeleton'); Niya $n d, n d h>m n n$ (bhimnnati 'splits' < OIA bhindati, bamnnanae 'to bind' $<$ OIA bandhati 'binds'), Punjabi, Lahnda, West Pahari $n d, n d h>n n$, nnh (Punjabi cannan 'sandalwood' < OIA candana-, Lahnda, Punjabi, Chameali bannh- 'to bind' < OIA bandhati 'binds'). The data, however, are too scanty to be conclusive.

The scarceness of material is also a major obstacle to lexicostatistical analysis. The Swadesh list for Niya contains more than 40 lacunae, which renders any calculations inexpedient, because the resulting tree, in all likelihood, will not always properly reflect the real picture of genetic relations. The most conspicuous peculiarity of this incomplete list is the large proportion of archaisms unknown in later Indo-Aryan. They include such lexical items as utarā 'belly' (< OIA udara-), mahaṃta 'big' (< OIA mahant-), kriṣaǵa 'black' (< OIA krșna-), śune 'dog' (< OIA śvan-/śun-), asiya 'mouth' (< OIA āsya-), pamtha 'road' (< OIA panthā-), siǵata 'sand' (< OIA sikatā-), udaǵa 'water' (< OIA udaka-), veyam 'we' (< OIA vayam), śpeta, śpedaǵa 'white' (< OIA śveta-). All these words were used in "Swadesh meanings" in Old Indic, but none of them is preserved, at least with the original semantics, in New Indo-Aryan languages ${ }^{43}$. The only probable classifying lexical isogloss detected in the Swadesh list is Niya rataǵa 'red' (cf. Punjabi, Lahnda, Hindko rattā, Sindhi rato, Marwari rātau, Gujarati rātũ, West Pahari (Kotgarhi) ratts 'red' < OIA rakta( $k a)$ - 'colored, dyed'). As should be evident from the examples cited, this isogloss brings the Niya Prakrit closer to the languages spoken in the west and northwest of the Indo-Gangetic Plain as well as in the adjoining Himalayan areas.

Thus, both phonological and lexical facts suggest that the region from which the Niya Prakrit was brought to East Turkestan was situated somewhere in the Northwestern part of the Indian subcontinent, in the basin of the Indus River. The phonological and morphological isoglosses analyzed by Burrow, as well as possible loanwords from Dardic, point to areas im-

\footnotetext{
${ }^{41}$ As noted above, the meaning 'worm' is attested in Old Indian.

${ }^{42}$ In Sanskrit this word represents an Iranian borrowing (Burrow 1934).

${ }^{43}$ The only exception is the word for 'water', preserved in Sinhalese (diya < OIA udaka) but completely lost in continental Indo-Aryan.
} 
mediately west of the Indus as the most likely original homeland of the Niya speakers. Nevertheless, given the natural limitations of our corpus, this last hypothesis should be considered as the likeliest option among several possible alternatives.

\section{Abbreviations for language names}

Av - Avestan; $\quad$ OIA - Old Indo-Aryan; $\quad$ PIE - Proto-Indo-European; $\quad$ PII - Proto-Indo-Iranian

\section{Питература}

Эдельман, Д. И. 1986. Сравнительная грамматика восточноиранских языков. Фонология. Москва: Наука.

Коган, А. И. 2005. Дардские языки. Генетическая характеристика. Москва: Восточная литература.

Коган, А. И. 2008. О статусе и происхождении звонкой придыхательной серии в ряде дардских языков. В: A. Куликов, М. Русанов (ред.). Orientalia et Classica. Труды Института восточных культур и античности. Выпуск XX. Indologica: 197-226. Москва: РГГУ.

Коган, А. И. 2016. Проблемы сравнительно-исторического изучения языка кашмири. Москва: Фонд развития фундаментальных лингвистических исследований.

Коган, А. И., М. Е. Васильев. 2013. К вопросу о восточнодардской языковой общности. Вестник РГГУ. Серия: Вопросы языкового родства 10: 149-178.

\section{References}

Bailey, H. W. 1948. Irano-Indica. Bulletin of the School of Oriental and African Studies, University of London 12 (2): 319-332.

Bailey, H. W. 1979. Dictionary of Khotan Saka. Cambridge - London - New York - Melbourne: Cambridge University Press.

Burrow, T. 1934. Iranian words in the Kharoșthi documents from Chinese Turkestan. Bulletin of the School of Oriental and African Studies, University of London 7 (3): 509-516.

Burrow, T. 1935. Tokharian elements in the Kharoșthi documents from Chinese Turkestan. The Journal of Royal Asiatic Society of Great Britain and Ireland 4: 667-675.

Burrow, T. 1936. The dialectical position of the Niya Prakrit. Bulletin of the School of Oriental and African Studies, University of London 8 (2/3): 419-435.

Burrow, T. 1937. The language of the Kharoșthi documents from Chinese Turkestan. London: Cambridge University Press.

Burrow, T. 1940. A Translation of the Kharoșthi Documents from Chinese Turkestan. London: The Royal Asiatic Society. Edelman, D. I. 1986. Sravnitel'naya grammatika vostochnoiranskikh yazykov. Fonologiya. Moskva: Nauka.

Hitch, Douglas A. 1988. Kushan Tarim domination. Central Asiatic Journal, Vol.32, No. 3/4: 170-192.

Hock, Hans Henrich, Elena Bashir (eds.). 2016. The languages and linguistics of South Asia: a comprehensive guide. Berlin/Boston: Walter de Gruyter GmbH.

Konow, S. 1936. Note on the ancient North-Western Prakrit. Bulletin of the School of Oriental and African Studies, University of London 8 (2/3): 603-612.

Kogan, A. I. 2005. Dardskie yazyki. Geneticheskaya kharakteristika. Moskva: Vostochnaya literatura.

Kogan, A. I. 2008. O statuse i proiskhozhdenii zvonkoy pridykhatel'noy serii v r'ade dardskikh yazykov. In: L. Kulikov, M. Rusanov (eds.). Orientalia et Classica. Papers of the Institute of Oriental and Classical Studies. Issue XX. Indologica. T. Ya. Elizarenkova Memorial Volume. Book 1. 197-226. Moscow: Russian State University for the Humanities.

Kogan, A. I. 2016. Problemy sravnitel'no-istoricheskogo izucheniya yazyka kashmiri. Moskva: Fond "Razvitiya fundamental'nykh lingvisicheskikh issledovaniy".

Kogan, A. I., M. E. Vasilyev. 2013. K voprosu o vostochnodardskoy yazykovoy obshchnosti. Journal of Language Relationship 10: 149-178. 
Mayrhofer, M. 1996. Etymologisches Wörterbuch des Altindoarischen. II Band. Heidelberg: Universitätsverlag Carl Winter.

Millward, James A. 2013. The silk road: a very short introduction. Oxford University Press.

Morgenstierne, G. 1947. Metathesis of liquids in Dardic. Det Norske Videnskapsakademi i Oslo. Skrifter 2: 145-154.

Pokorny, J. 1959. Indogermanisches etymologisches Wörterbuch. Bern-München: Francke Verlag, 1959.

Salomon, R. 2006. Recent discoveries of early Buddhist manuscripts and their implications for the history of Buddhist texts and canons. In: P. Olivelle (ed.). Between the Empires, Society in India 300 BCE to 400 CE: 349382. New York: Oxford University Press.

Stein, A. 1904. Sand-buried ruins of Khotan: personal narrative of a journey of archaeological and geographical exploration in Chinese Turkestan. London: Hurst and Blackett, Ltd.

Turner, R. L. 1966. A comparative dictionary of the Indo-Aryan languages. London: Oxford University Press.

А. И. Коган. Еще раз о языке документов из Ния (Восточный Туркестан) и его генетическом положении

Язык документов, обнаруженных на юго-востоке нынешнего Синьцзян-Уйгурского автономного района Китая, главным образом, в оазисе Ния, обычно рассматривается как среднеиндийский. В то же время ряд исследователей считает его возможным предком некоторых дардских языков. В настоящей статье делается попытка разрешить это противоречие и установить точное положение пракрита из Ния внутри индоиранской языковой общности. Автор приходит к выводу, что данный язык никоим образом не может быть отнесен к дардской группе, хотя в прошлом его носители могли являться соседями дардов.

Ключевые слова: индоарийские языки, дардские языки, классификация языков, историческая фонетика, северо-западный пракрит, пракрит из Ния, Восточный Туркестан, государство Крорайна. 